九州大学学術情報リポジトリ

Kyushu University Institutional Repository

The Change In Ascorbic Acid Content of Porphyra Tenera Due To Ecological And Processing Conditions

Katayama, Teruhisa

Laboratory of Chemistry of Fishery Product, Faculty of Agriculture, Kyusyu University

Tomi yama, Tetuo

Laboratory of Chemistry of Fishery Product, Faculty of Agriculture, Kyusyu University

https://doi.org/10.5109/22631

出版情報: 九州大学大学院農学研究院紀要. 9 (3)，pp. 275-281，1950-01. Kyushu University バージョン：

権利関係 : 
Journal of the Faculty of Agriculture, Kyüshü University, Vol. 9, No. 3

January 31, 1950

\title{
THE CHANGE IN ASCORBIC ACID CONTENT OF PORPHYRA TENERA DUE TO ECOLOGICAL AND PROCESSING CONDITIONS
}

\author{
Twruhisa Katayama and Tetuo Tomyama
}

The divergent values have been reported so far for ascorbic acid of dried product of Porphyra tenera K., e.g., $664-821 \mathrm{mg}$ per cent (Oya and Hirozawa) (1), $243 \mathrm{mg}$ per cent (Fujita and Ebihara) (2), and 10-15 mg per cent (Nitta et al) (3). In order to make the cause of these variations clear, a study has been made on the variations in ascorbic acid content of fresh Porphyra, on one hand, due to the differences in growth and environment and of dried product, on the other, due to the difference in procedure for drying or storage.

The present work has clearly shown that the variation in ascorbic acid content of dried Porphyra is not due to the inconsistent content of ascorbic acid in fresh material itself but mostly due to procedures for storage of dried Porphyra.

\section{Thi METHOD For Determination of Ascorbic ACID}

The samples were taken from bamboo-collectors around the estuary of Tatara river in the vicinity of Fukuoka city. The alga was blotted free of excess water with filter paper immediately before the determination. The ascorbic acid was determined upon extracts of Porphyra using Okuda and Katai's method (4) with a modification of Mitsuda's procedure (5) for removing an inherent reddish color. The determination has been carried out as follows. To an appropriate amount of the sample $(2-3 \mathrm{~g})$ add twice its amount of cold ten per cent metaphosphric acid together with a smal! amount of silicic sand. After grinding it in a mortor, dilute 
it tenfold with cold water, and leave stand for $30 \mathrm{~min}$. in ice-cold water stirring frequently. After centrifuging the extract, add a small quantity of acid clay and then filter. Titrate the filtrate in the usual with a cold solution of 2,6-dichlorphenol indophenol.

\section{The Variation in Ascorbic Acid Content due to Ecological Conditions}

\section{The effect of growth rate and assimilation upon the content}

The determination has been made of ascorbic acid of Porplyyra which had different sizes and was gathered in different season. The results are shown in Table 1 . The ascorbic acid content was found always to be about $60-65 \mathrm{mg}$ per cent and did not show any relation to the gathering season or the sizes of individuals.

Table 1. Change in ascurbic acid content with growth rate and assimilation.

\begin{tabular}{|c|c|c|c|c|c|c|}
\hline \multirow{2}{*}{\multicolumn{3}{|c|}{ Length of Porphyra }} & \multirow{2}{*}{\multicolumn{2}{|c|}{ Date of gathering }} & \multicolumn{2}{|c|}{ Effect of assimilation } \\
\hline & & & & & Collected & Irradiated \\
\hline$\because 15 \mathrm{~mm}$ & $7-15 \mathrm{~mm}$ & $\leq 7 \mathrm{~mm}$ & $10 \mathrm{Dec}$. & y Jan. & at 9 a.m. & for 5 hours* \\
\hline 63.0 & 60.1 & 64.7 & 65.1 & 64.8 & 59.1 & 57.3 \\
\hline
\end{tabular}

It has been reported that the content of ascorbic acid in spinach shows more or less diurnal variation (6). Experiments have been made, accordingly, to see the effect of assimilation on the change in the ascorbic acid content. Freshly collected Porphyra was placed in sea water in a glass dish and one part of it was exposed to solar radiation while the other was covered with a box. After five hours elapsed, both were analyzed for ascorbic acid. Data given in Table 1 show that ascorbic acid content does not change in appreciable amount with assimilation.

\section{The variation due to the change of conditions of environment for Porphyra}

Some experiments have been carried out to see extent of effects of various factors. which may govern ascorbic acid content 
of Porphyra while being alive in sea water or being preserved before drying.

The effect of $\mathrm{pH}$ was examined in the following way. Put a freshly collected Porphyra in sea waters having different $\mathrm{pH}$ 's which were adjusted by adding varying amounts of hydrochloric acid. Leave them stand for 12 hours at temperature ranging from 8 to $13{ }^{\circ} \mathrm{C}$. and analyzed for ascorbic acid. The result is shown in Fig. 1. It will be seen that ascorbic acid of living Porphyra is fairly stable within a wide range of $\mathrm{pH}$ values of the medium, especially in alkaline region.

The effect of temperature has been observed by dipping a freshly collected alga in sea waters having salinity of $27.1 \%$ and temperatures ranging from 0 to $35^{\circ} \mathrm{C}$. for 12 hours. Fig. 1 shows that ascorbic acid decreases with the rise in temperature. The extent of the decrease was not appreciable below $20^{\circ} \mathrm{C}$.

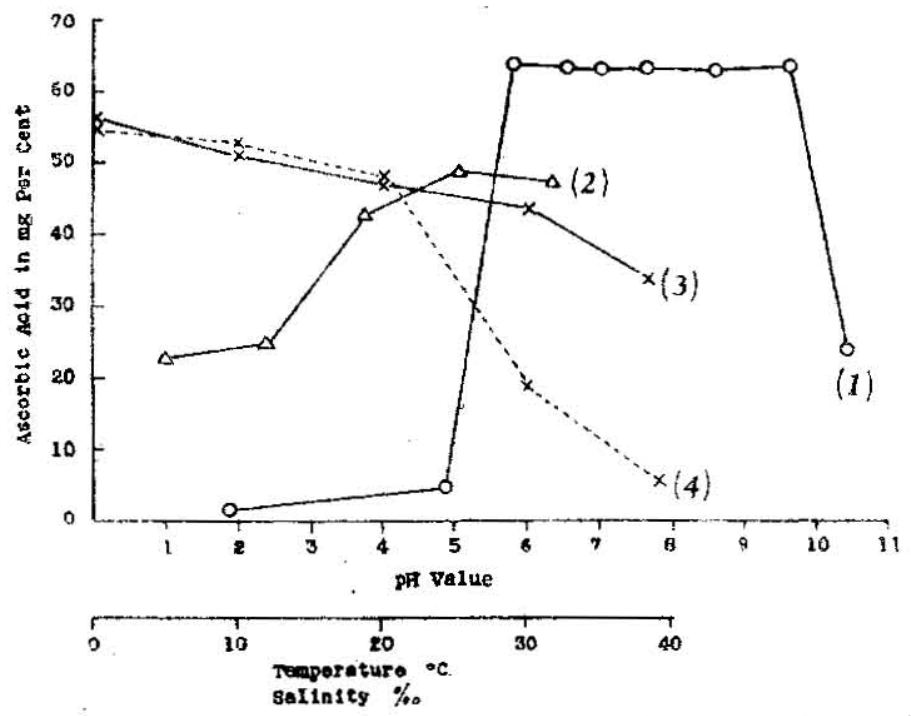

Fig. 1 Effects of several factors governing ascorbic acid content of living Porphyra. Curve 1 shows effect of $\mathrm{pH}$; Curve 2, effect of salinity: Curve 3 and 4 , effect of temperature for 3 hours and 12 hours. respectively.

The effect of salinity has been tested by leaving a freshly collected alga stand for 24 hours at temperatures ranging from 7 to $12^{\prime} \mathrm{C}$. in sea water, salinity of which was adjusted to varying 
values by diluting it with distilled water. It will be apparent from Fig. 1 that no decrease in ascorbic acid was observed above salinity of $18 \%$

\section{The Variation in Ascorbic Acid Con'ent during; the Manufacture of Dried Porphyra}

1. The effect of ascorbic acid oxidase upon the content

It has been well known that the decrease in ascorbic acid on processing vegetables is generally infuenced by the activity of ascorbic acid oxidase. By adopting the Iwata's procedure (7), a socalled stable form of ascorbic acid has been estimated, i.e., after grinding up $2 \mathrm{~g}$ of Porphyra with silicic sand, leave it stand for varying time-intervals, add metaphosphoric acid so as to make 2 per cent solution, and titrate the remaining ascorbic acid. It will be seen from Table 2 that the oxidase in Porphyra is not so active and the stable form of ascorbic acid is about 63 per cent. On examination of the figures given in Iwata's paper for the stablc form of ascorbic acid in 141 samples of vegetables, it will be noticed that only 5 per cent of them contain the amount of the stable form which is comparable to that of Porphyra. Taking into consideration the stability and richness of ascorbic acid in Forphyra, it can be said that it is one of the important natural sources of ascorbic acid.

Table 2. Effect of oxidase upon ascorbic acid content of fresh and dried Porphyra.

\begin{tabular}{|c|c|c|c|c|c|}
\hline \multirow{2}{*}{$\begin{array}{c}\text { Time in } \\
\text { min. after } \\
\text { maceration }\end{array}$} & \multicolumn{2}{|c|}{$\begin{array}{l}\text { Ascorbic acid of } \\
\text { fresh Porphyra }\end{array}$} & \multicolumn{3}{|c|}{ Ascorbic acid of dried Porphyra } \\
\hline & $\mathrm{mg} \%$ & $\begin{array}{c}\% \\
\text { remained }\end{array}$ & $\begin{array}{l}\text { heated } \\
\text { at } 100^{\circ} 30^{\prime} \\
\mathrm{mg} \%\end{array}$ & $\begin{array}{c}\text { heated over } \\
\text { heater } \\
\text { mg \% }\end{array}$ & $\begin{array}{l}\text { Control } \\
\text { mg \% }\end{array}$ \\
\hline 0 & 63.3 & 100 & 290 & 290 & 284 \\
\hline 5 & 39.2 & 62 & 259 & 266 & 208 \\
\hline 10 & 40.0 & 63 & 231 & 258 & 198 \\
\hline 15 & 41.5 & 65 & & & \\
\hline 50 & 40.0 & 63 & & & \\
\hline
\end{tabular}

Since it is a cold climate where Porphyra is gathered, the tissue may be frozen and the decrease in ascorbic acid will be 
caused by the action of the oxidase. The decrease on keeping Porbinyra for 5 hours at $-10^{\circ} \mathrm{C}$. has been observed as shown in Table 3. Because of the fact that the amount of the remaining ascorbic acid $(76 \%)$ approximates to the so-called stable form of ascorbic acid $(63 \%)$, a remarkable decrease in ascoibic acid may be most probably due to the ascorbic acid oxidase. When the frozen alga was dried, however, the remaining ascorbic acid was only 29 per cent. This may be accounted for by a simultaneous action of the oxidase and the auto-oxidation.

\section{The change of ascorbic acid with conditions for drying}

Several experiments have been carried out to see the extent of decrease in ascorbic acid content on drying Porphyra. It has been shown in Table 3 that when drying was carried out over a fairly long duration the decrease in ascorbic acid was remarkable, whereas only a slight decrease was observed on a quick drying no matter whether the drying was carried out by exposing to sunlight or by artificial heating.

Table 3. Effect of freezing and drying upon ascorbic acid content.

\begin{tabular}{|c|c|c|c|c|c|c|}
\hline & \multicolumn{3}{|c|}{ Effect of freezing } & \multicolumn{3}{|c|}{ Effect of drying } \\
\hline & $\begin{array}{l}\text { before } \\
\text { freezing }\end{array}$ & $\begin{array}{l}\text { after } \\
\text { being } \\
\text { frozen }\end{array}$ & $\begin{array}{l}\text { after } \\
\text { drying } \\
\text { frozen } \\
\text { sample }\end{array}$ & 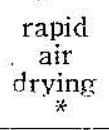 & $\begin{array}{l}\text { slow } \\
\text { air } \\
\text { dryings } \\
\text { wit }\end{array}$ & $\begin{array}{c}\text { dried in } \\
\text { electric } \\
\text { draft drict } \\
* * * *\end{array}$ \\
\hline $\begin{array}{l}\text { Ascorbic } \\
\text { acid mg \% }\end{array}$ & 51.1 & 39.5 & 14.9 & 292 & 141 & 320 \\
\hline $\begin{array}{l}\text { Per cent } \\
\text { destroyed }\end{array}$ & & 24 & 71 & 16 & 50 & 8 \\
\hline
\end{tabular}

\section{The change of ascorbic acid during storage of dried Porphyra}

It may be presumed that the change of ascorbic acid during the storage will take place because of humidity and the ascorbic acid oxidase. In order to see the effect of humidity, a dried 
Porphyra was put, on one hand, in a desiccator containing calcium chloride and, on the other, in a desiccator containing $\mathrm{Na}_{2} \mathrm{SO}_{4} \cdot 7 \mathrm{H}_{2} \mathrm{O}$ which shows a vapor tention of $13.2 \mathrm{~mm} \mathrm{Hg}$ at $20^{\circ} \mathrm{C}$. The change in ascorbic acid content was traced for about two weeks. To see the extent of the effect of ascorbic acid oxidase, a dried alga which was heated at $100^{\circ} \mathrm{C}$. for $30 \mathrm{~min}$. or directly over an electric heater was preserved in the same conditions as above.

As will be apparent from Fig. 2, the decrease in ascorbic acid of the dried Porphyra was very marked when kept in a

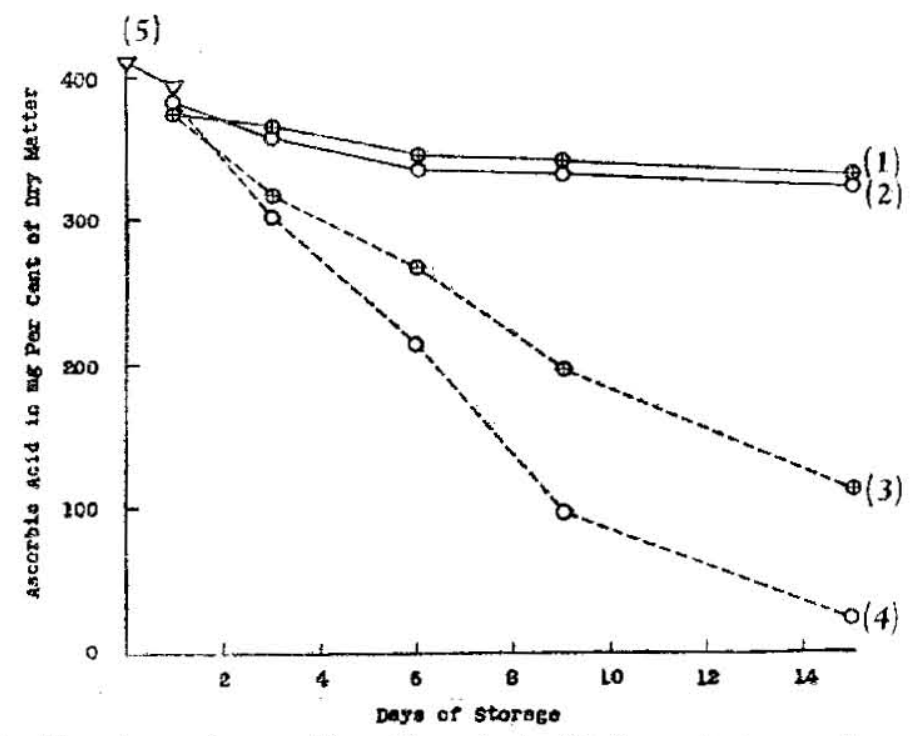

Fig. 2. The change in ascorbic acid content with time of storage depending, on whether in dry or humid condition. Curue 1 and 2 show the change in a desiccator containing $\mathrm{CaCl}_{2}$; Curve 3 and 4 , the change in a desiccator containing $\mathrm{Na}_{2} \mathrm{SO}_{4} \cdot 7 \mathrm{H}_{2} \mathrm{O}$; Curve 1 and 3 , experiment on Porphyra beated at $100^{\circ}$ for $30 \mathrm{~min}$.; Curve 5, the change in fresh Porphyra while preserving in water overnight.

humid chamber. The decrease in ascorbic acid content of an air dried Porphyra which had been heated at $100^{\circ} \mathrm{C}$. was observed to be less than that of air dried Porphyra without any treatment. On the other hand, data presented in Table 2 clearly show that the ascorbic acid oxidase in air dried Poryhyra is as much active as in fresh one and heating at $100^{\circ} \mathrm{C}$. for $30 \mathrm{~min}$. destroys the oxidase to a certain degree. These evidences will indicate that 
the change in ascorbic acid during preservation took place due tc a combined action of humidity and the ascorbic acid oxidase.

\section{SUMmary}

1. An appreciable change in ascorbic acid was not noticed during the growth of Porphyra.

2. The diurnal change in ascorbic acid was not appreciable.

3. A freshly collected Porphyra, when preserved in water having $\mathrm{pH}$ values of $5.8-9.8$ and salinity values higher than $18, v$ did not show the decrease in ascorbic acid content. When preserved at temperatures above $20^{\circ} \mathrm{C}$., the content of ascorbic acid decreased somewhat after 3 hours, but decreased to a great extent after 12 hours.

4. The ascorbic acid content of Porphyra shows almost no change on being preserved in a dry atmosphere.

5. It has been pointed out that the extent of the decrease during the preservation in a humid atmosphere is enough to account for the discorcant values of ascorbic acid of dried Porphyra. Evidences have been presented that the change will most probably take place due to a combined action of humidity and the ascorbic acid oxidase.

The authors wish to express their hearty thanks to Mr. T. Yabuki and Miss S. Nakao for their assistance in carrying out some parts of the work. Thanks are also extended for a grant from the Research Fund of the Ministry of Education.

Laboratory of Chemistry of Fishery Product, Faculty of Agriculture, Kyushu Liniversity, August 1949

\section{REFERENCES}

(1) Oya and Ilirozawa: Jap. Soc. Scient. Fish., 5, 195 (1936).

(2) Fujita and Ebihara: Tokyo Iji Shinshi, 2966, 237 (1936).

(3) Nitta, Taguchi and Mori: Jap. Soc. Scient. Fish., 13, 153 (1948).

(4) Okuda and Katai: J. Agric. Chem. Soc. Japan, 15, 80 (1939).

(5) Mitsuda: ibid., 14, 1228 (1938).

(6) Sugawara: Jap. J. Botany, 11, 343 (1941).

(7) Iwata et al: J. Agric. Chem. Soc. Japan, 18, 673, 1058 (1942). 